\title{
PEMANFAATAN MEDIA PEMBELAJARAN BERBASIS GAME EDUKASI KAHOOT! PADA PEMBELAJARAN FISIKA
}

\author{
Rafika Andari ${ }^{1}$ \\ 1)Program Studi Teknik Elektro, Fakultas Teknik, Institut Teknologi Padang, Padang, Indonesia \\ Corresponding author : Rafika Andari \\ E-mail : rafika.andari09@gmail.com
}

Diterima 10 April 2020, Disetujui 27 April 2020

\begin{abstract}
ABSTRAK
Tujuan penelitian ini untuk mengetahui pemanfaatan media pembelajaran berbasis game edukasi terhadap peningkatan hasil belajar mahasiswa. Penelitian ini merupakan penelitian dan pengembangan (research and development) yang digunakan untuk menghasilkan produk tertentu dan menguji keefektifan produk tersebut. Pengumpulan data menggunakan metode angket, tes, dan dianalisis secara deskriptif kuantitatif. Sampel penelitian yaitu mahasiswa angkatan 2019 program studi Teknik Elektro kelas A dan kelas B. Teknik pengambilan sampel menggunakan purposive sampling, Kelas A sebagai kelompok eksperimen dan Kelas B sebagai kelompok kontrol. Hasil belajar kelompok mahasiswa yang memanfaatkan media game edukasi kahoot! lebih baik $(34,6 \%)$ dibandingkan dengan kelompok mahasiswa yang menggunakan media power point.
\end{abstract}

Kata Kunci : kuantitatif; kuis interaktif; kahoot!; hasil belajar.

\begin{abstract}
The purpose of this research to find out the uses of learning media game education on the increase in student learning outcomes. The research is of research and development research and development that is used to produce certain products and test the current effectiveness of that product.Such data collection uses the method, a test, and analyzed a sort of descriptive set quantitative .Namely research sample class student 2019 course of study electrical engineering class A and class B. The sampling method of collecting samples using purposive technique, as a group of experimentation and class a class $b$ as the control group .Learning outcomes group of students who use media education kahoot game ! is the best $34,6 \%$ ) in comparison to groups of students who uses the media power point.
\end{abstract}

Keywords: quantitative; interactive quiz; kahoot!; learning outcomes.

\section{PENDAHULUAN}

Perkembangan ilmu pengetahuan dan teknologi yang semakin pesat mempengaruhi segala aspek kehidupan manusia tidak terkecuali dalam bidang pendidikan. Di Era Revolusi Industri 4.0 saat ini menjadikan perguruan tinggi harus mampu beradapatasi dengan perkembangan teknologi, salah satunya menciptakan agar proses pembelajaran menjadi kondusif dan menyenangkan. Guru, dosen dan Pengembang Teknologi Pembelajaran memiliki peran penting dalam hal mengembangkan inovasi, ide atau gagasan untuk pemanfaatan teknologi dalam pembelajaran. (Made Wena, 2011) menyatakan keuntungan pembelajaran dengan teknologi dapat menciptakan iklim belajar yang efektif bagi siswa yang lamban dalam pembelajaran, merangsang siswa dalam mengerjakan latihan dan dapat menyesuaikan kecepatan kecepatan belajar dapat sesuai dengan kemampuan mahasiswa.
(Tejo Nurseto, 2011) Pemanfaatan teknologi sebagai media pembelajaran untuk mempermudah baik bagi pengajar maupun peserta didik dalam mengelola, menyampaikan informasi serta menjadikan pengalaman belajar yang berbeda.

Untuk mendapatkan keterampilan dan pemahaman belajar, mahasiswa perlu diberi semangat untuk menghasilkan ide-ide baru, mengevaluasi dan menganalisa materi yang diajarkan dan mampu mengaplikasikan apa yang telah mereka pelajari. Hal tersebut bisa dicapai dengan memberikan kesempatan kepada mahasiswa untuk terlibat lebih aktif dengan kegiatan interaktif secara online. Banyak aplikasi computer dan website yang dapat memfasilitasi belajar siswa secara aktif dan interaktif dengan memberikan kesempatan kepada siswa untuk menelaah kembali informasi dan mempraktikan pengetahuan atau keterampilan mereka sambil menikmati permainan. 
Secara umum diketahui permainan bersifat menyenangkan dan motivasi. Beberapa literatur mengungkapkan bahwasanya pembelajaran yang bersifat pendekatan permainan yang melibatkan partisipasi peserta didik dalam teknologi digital, menunjukkan keingingan yang lebih besar dalam melanjutkan proses pembelajaran berikutnya dibandingan pembelajaran bersifat konvensional. (Ryan Dellos, 2015) menyatakan bahwa pembelajaran berlandasan permainan merupakan alat yang dapat membantu peserta didik dalam menyelesaikan masalah, meningkatkan pemikiran kritis dan membuat sebuah penilaian dalam proses pembelajaran. (Sutirna, 2018) Game education (permainan edukatif) adalah sebuah permainan yang digunakan dalam proses pembelajaran dan dalam permainan tersebut mengandung unsur mendidik atau nilai-nilai pendidikan.

Kahoot merupakan salah satu media pembelajaran interaktif yang dapat digunakan guna menjadikan proses pembelajaran menjadi menyenangkan dan tidak membosankan baik bagi peserta didik maupun bagi pengajar karena aplikasi Kahoot menekankan gaya belajar yang melibatkan hubungan peran aktif partisipasi peserta didik dengan rekan-rekan sejawatnya secara kompetitif terhadap pembelajaran yang sedang atau telah dipelajarinya (Harlina, Nor, \& Ahmad, 2017). Kelebihan dari Kahoot ini adalah bentuk aplikasinya berupa kuis online yang mengandung unsur persaingan karena hasil kuis dapat langsung terlihat di layar kelas sehingga dapat dijadikan motivasi belajar mahasiswa untuk memperoleh poin, serta dapat digunakan melalui berbagai media seperti computer, laptop, tablet dan android.

Kahoot memiliki empat fitur yaitu: game, kuis, diskusi dan survey. Untuk game, terdapat pilihan membuat jenis pertanyaan, dan menentukan jawaban yang paling tepat serta waktu yang digunakan untuk menjawab pertanyaan tersebut. Uniknya, jawaban nantinya akan diwakili oleh gambar dan warna. Peserta diminta memilih warna/gambar yang mewakili jawaban.

Berdasarkan hasil pengamatan dalam proses pembelajaran ditemui beberapa fakta yaitu rendahnya pemahaman mahasiswa menyelesaikan soal yang berhubungan dengan teori pada materi gaya magnet. Hal itu dikarenakan mahasiswa berpikir abstrak dalam suatu materi yang diberikan. Oleh karena itu, peneliti berupaya menggunakan kuis interaktif kahoot! sebagai media pembelajaran agar mahasiswa langsung mendapatkan hasil evaluasi (feedback). Dengan adanya media pembelajaran kuis interaktif kahoot! diharapkan dapat meningkatkan hasil belajar mahasiswa dalam proses pembelajaran.

\section{METODE PENELITIAN}

Metode penelitian yang digunakan dalam penelitian ini adalah penelitian metode penelitian dan pengembangan (Research and Development). Research and Development adalah metode penelitian yang digunakan untuk menghasilkan produk tertentu, dan menguji keefektifan produk tersebut.

Subjek penelitian adalah mahasiswa Program Studi Teknik Elektro Institut Teknologi Padang angkatan 2019. Penelitian yang telah dilaksanakan yaitu evaluasi pembelajaran dalam bentuk kuis interaktif yang diaplikasikan dengan aplikasi Kahoot pada mata kuliah Fisika 1 khususnya materi gaya magnet. Sampel terdiri dari dua kelas, yaitu kelas $A$ sebagai kelas kontrol dengan penerapan kuis berbasis power point dan kelas B sebagai kelas eksperimen dengan kuis berbasis interaktif menggunakan kahoot!. Desain penelitian menggunakan pola post-test only control group design. Teknik pengumpulan data menggunakan teknik post-test untuk mengukur hasil belajar mahasiswa dan metode angket untuk mengetahui motivasi belajar mahasiswa.

\section{HASIL DAN PEMBAHASAN}

Hasil penelitian yang dilakukan oleh peneliti yaitu berupa nilai pengetahuan yang diperoleh dari nilai post-test mahasiswa. Data tanggapan mahasiswa diperoleh dari hasil pembagian angket kepada mahasiswa mengenai tanggapan terhadap pemanfaatan media game edukasi Kahoot! yang ditabulasi dan dihitung perbandingan persentase tanggapan mahasiswa. Perbandingan tanggapan mahasiswa tersebut dapat dilihat pada gambar 1 .

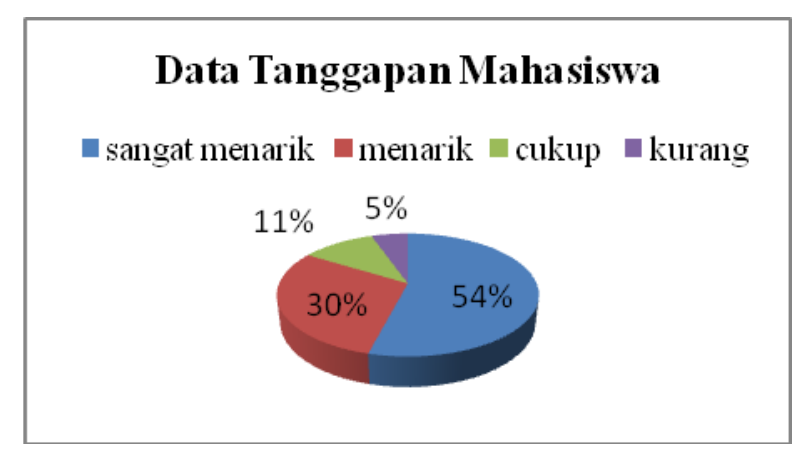

Gambar 1. Data Tanggapan Mahasiswa.

Berdasarkan Gambar 1. terlihat bahwa sebanyak 20 mahasiswa $(54,1 \%)$ memiliki tanggapan sangat menarik terhadap pemanfaatan media game edukasi Kahoot!, 11 
mahasiswa $(29,7 \%)$ memiliki tanggapan menarik, 4 mahasiswa (10,8\%) tanggapan cukup dan hanya 2 mahasiswa $(5,4 \%)$ tanggapan kurang menarik.

Berdasarkan pengujian terhadap hasil belajar mahasiswa terdapat perbedaan yang signifikan antara kelompok eksperimen dan kelompok kontrol. Perbedaan ini diperoleh dari hasil belajar kedua kelompok dengan selisih sebesar 6,2 satuan dengan rincian sebesar 87 untuk kelompok eksperimen dan 79,8 untuk kelompok control. Hasil ini diperoleh dari penjumlahan nilai post-test mahasiswa seperti pada Tabel 1.

Tabel 1. Deskripsi Nilai Post-test

\begin{tabular}{lll}
\hline Nilai & $\begin{array}{l}\text { Rata-rata } \\
\text { Eksperimen }\end{array}$ & $\begin{array}{l}\text { Rata-rata } \\
\text { Kontrol }\end{array}$ \\
\hline Post-test & 87 & 79,8 \\
\hline
\end{tabular}

Berdasarkan Tabel 1. Terdapat perbedaan hasil belajar mahasiswa kelas eksperimen dan kelas kontrol yang disebabkan karena lebih aktifnya mahasiswa kelas eksperimen dibandingkan dengan mahasiswa kelas control dalam pelaksanaan kuis. Selain itu juga mahasiswa kelas eksperimen langsung mendapatkan umpan balik (feedback) dari hasil kuis yang dilaksanakan, sehingga pemahaman dan evaluasi kembali terhadap materi langsung diberikan. Motivasi dan antusias dari mahasiswa kelompok eksperimen lebih tinggi berdasarkan rubrik penilaian sebesar $86 \%$ mahasiswa lebih siap mengikuti kuis dibandingkan mahasiswa kelompok kontrol yang hanya $65 \%$.

Pengujian hasil belajar mahasiswa kelompok eksperimen yang menggunakan bantuan aplikasi SPSS terhadap pemanfaatan media game edukasi kahoot! cukup berpengaruh sebesar $34,6 \%$ dan skor hasil belajar meningkat 0,57 satuan. Hasil rata-rata menunjukkan bahwa sebesar 90,1\% merupakan sumbangan pengaruh pemanfaatan media game edukasi kahoot!. dapat disimpulkan jika semakin tinggi skor penggunaan media game, maka semakin tinggi pula skor hasil belajar mahasiswa.

Skor media kuis setiap mahasiswa yang diperoleh dari tabulasi data angket tanggapan mahasiswa terhadap pemanfaatan media game semakin baik terbukti dengan hasil skor total yang dicapai semakin baik. Hal ini dapat diartikan bahwa dengan pemanfaatan media game yang lebih memotivasi dan antusiasme mahasiswa juga akan lebih baik sehingga berpengaruh terhadap hasil belajar. Pemanfaatan media game edukasi Kahoot! Ini dapat mempercepat pemahaman mahasiswa terhadap materi yang telah diajarkan karena memberikan umpan balik (feedback) secara langsung. Mahasiswa juga dapat lebih memantapkan kembali dan berani menyampaikan materi yang dirasa kurang paham.

\section{SIMPULAN DAN SARAN}

Berdasarkan hasil penelitian dan pembahasan, maka dapat disimpulkan bahwa hasil belajar kelompok mahasiswa yang memanfaatkan media game edukasi kahoot! lebih baik $(34,6 \%)$ dibandingkan dengan kelompok mahasiswa yang menggunakan media power point. Ketuntasan belajar mahasiswa kelompok eksperimen (87\%) pada saat post-test lebih tinggi dibandingkan dengan mahasiswa kelompok control $(79,8 \%)$.Terdapat perbedaan hasil belajar mahasiswa kelas eksperimen dan kelas kontrol yang disebabkan karena lebih aktifnya mahasiswa kelas eksperimen dibandingkan dengan mahasiswa kelas kontrol dalam pelaksanaan kuis. Selain itu juga mahasiswa kelas eksperimen langsung mendapatkan umpan balik (feedback) dari hasil kuis yang dilaksanakan, sehingga pemahaman dan evaluasi kembali terhadap materi langsung diberikan.

\section{DAFTAR RUJUKAN}

Harlina, Nor, Z. M., \& Ahmad, A. (2017). Pembelajaran Interaktif Berasaskan Aplikasi Kahoot dalam Pengajaran Abad Ke-21. Seminar Serantau, 627635. Retrieved from https://seminarserantau2017.files.word press.com/2017/09/74-harlina-bintiishak.pdf.

Made Wena. (2011). Strategi Pembelajaran Inovatif Kontemporer. Jakarta: Bumi Aksara.

Ryan Dellos. (2015). Kahoot! A digital game resource for learning. In International Journal of Instructional Technology and Distance Learning Vol 12 (pp. 4952). Retrieved from https://scholar.google.co.kr/citations?u ser=irAHXE4AAAAJ\&hl=en\#d=gs_md cita-

$\bar{d} \& p=\& u=\% 2 F$ citations $\% 3 F v i e w \_o p \% 3$ Dview_citation\%26hl\%3Den\%26user\% 3DirA-̄XE4AAAAJ\%26citation_for_vie w\%3DirAHXE4AAAAJ\%3Au5H HmVD_ uO8C\%26tzom\%3D-420

Sutirna. (2018). Seminar Nasional Semnas Ristek. In Peran Teknologi Informasi dalam Mendukung Stabilitas Nasional (pp. 269-276). Jakarta.

Tejo Nurseto. (2011). Membuat Media Pembelajaran yang Menarik. Ekonomi Dan Pendidikan, 8(1), 19-35. 